PROSE

\title{
The Sea of Red and White Anita Zuljan
}

Location: Zurich, Switzerland

Date: 18 June 2012

Time: 19:30

The HalF-TIME whistle blew. Football spectators made their way out of the city square, and away from the large TVs that were playing the European cup from every angle. Red and white checkered jerseys filled the city streets, with only an occasional glimpse of a Spanish jersey in site. Red smoke coming from flares filled the entire open area, making it hard to see all the people that were standing in my vicinityalthough the beer breath and distorted chanting gave it away. Football fans occupied the street bars, singing in their native tongue.

I finished my drink and made my way to a building opposite the main TV. There, I spotted Matthew, my boyfriend, who had been captivated by the Italy match while I had been fascinated with the Croatia vs. Spain game.

"Close match?" He asked.

"Still 0-0," I replied.

Even though no-one had scored, the atmosphere was like nothing I had ever experienced before. For most of the time, my eyes had been fixed on the chanting, jumping, screaming diehard fans that looked as though they had been hypnotised by the football since kick off.

They lived and breathed for this sport - I could see it in their hungry eyes. I had been to A-League games in Melbourne before, but nothing would ever compare to this night. 
I spotted the crowd beginning to huddle up together again - the second half was about to commence. I left Matthew with his new found football friends and headed over to the group of relatives I had watched the first half with.

Forty-five minutes could not have passed any sooner. Before I knew it, there was only five minutes left in the game and the score was still $0-0$. I looked away from the screen and caught a glimpse of Matthew celebrating. Italy must have scored, I told myself, lucky bastard.

I focused back to the big screen in front of me and saw the scoreboard change: Croatia 0-1 Spain.

The city square erupted in anguish as the Croatian fans realised that they would not be going through to the next round of the tournament. I let out a loud sigh and began to head back to Matthew to tell him the final score.

As I turned my back to the crowd, a piercing sound filled my ears. I saw glass shatter in front of me. I turned around and faced the city square, realising what had happened.

Football hoons did not have the same reaction to that of my own, and before anyone knew it, the beautiful city of Zurich had been transformed into a haven for thugs.

Glass exploded everywhere.

Tables and chairs flew through the night sky.

Grown men transformed into blood thirsty cannibals, preying on the weak.

In front of me, five grown men covered in red and white had pinned another down on the ground and were laying into him-blow after blow, as though he were their new punching bag.

I stared at them, taking them in as if I were looking into their souls, only to realise they no longer had them.

I realised that I had to make a run for it.

I had to find Matthew and we had to get out of the streets of anarchy and find some place that was safe until control was restored.

I tried to lift my feet off the concrete ground but they were stuck.

I tried to scream his name but nothing came out of my mouth.

I was paralysed.

I was in the middle of a city I didn't know, surrounded by vicious strangers that had visibly lost their minds.

The stench of beer captivated my senses and my hands began to sweat. 
Beads of salty water cascaded down my forehead.

I could feel my heart striking my throat, as if it wanted to break free from the constraints of my body.

The sea of red and white checks was now overthrown by a sea of chaos.

As my eyes desperately darted around the city square I caught a glimpse of Matthew, and in that single moment I was free.

I raced towards the tall building that he had been watching the Italy match in, evading as many flying beer bottles that were being thrown in my direction as possible.

I reached towards the door knob only to discover that it was locked. They must have locked it when the fight broke out, I realised.

Frantically, I searched the building for another way in, praying that I would be reunited with Matthew before the sea of chaos engulfed me into its current.

I spotted a wooden door on the side of the building that had a gap big enough for me to crawl underneath.

I got down on my hands and knees and slowly made my way inside the building. As soon as I reached the other side my fears vanished-I knew that Matthew was in the room - he had to be.

"Matthew," I called, but no one responded. "Mathew," I repeated. "Matthew!"

I searched the room with my eyes, scanning the crowd to find the only person who could make me feel safe and secure.

He wasn't there.

My fear erupted and I began to panic. My breathing began to grow heavy and I could feel my heart begin to pulsate in my chest again.

I carelessly slid underneath the gap below the wooden door, grazing my knee in my haste to get back outside.

I got up and saw that the bloodthirsty football hoons were still terrorising the streets of Zurich.

I stood there- motionless.

I was powerless.

I was alone.

My head was telling me to keep searching, that I would find him eventually, but my heart had had enough.

I planted my feet steadily on the ground beneath me and took in all of my surroundings. 
Standing there, I couldn't help but picture the city that had welcomed me and the city that I was now alone in and scared of. I had only arrived in Zurich that morning. When I had arrived in the city square that evening, the ambiance was mesmerising. I remember looking up into the night sky, expecting to see countless stars gazing down at me. Instead, I had been welcomed with TVs and lights that brightened the night sky so much that not even a twinkling of a star could be seen above me.

A police siren roared behind me, snapping me back into reality.

I watched as the football hoons were restrained, officers appearing in every direction I turned. I heard a chorus of screams as the riot police emerged, aiming their water cannons at anyone that they perceived as a threat.

Finally, I thought. Control.

My worries may have been eased as a result of the presence of the police officers, but they were far from over.

I was still alone, and I still needed to find Matthew.

I felt a cold hand touch my shoulder, the other hand rest firmly on my waist.

I immediately turned around to face the creature that had dared to invade my personal space.

In that exact moment, every doubt I had had faded; my worries and my fears disappeared like the sea of red and white chaos.

"Matthew," I exclaimed, pulling him as close to my body as possible.

As he began to explain what had happened, a rush of emotions overcame me. I realised that the events of that night were meaninglessit didn't matter what had happened, how it happened or even why. All that mattered was that we were both okay. We were no longer alone in a foreign city - we were together.

The sea of chaos had come to an end. The current that had attempted to engulf me, one too many times, was now under control. The city that had once welcomed me with its bright lights, roaring crowds and hypnotic atmosphere was finally put to sleep, and so too were all my worries. 